\title{
Distribution of macrobenthic crustaceans associated with Thalassia, Halodule and bare sand substrata
}

\author{
F. Graham Lewis, III \\ Harbor Branch Institution, Inc., RR 1, Box 196A, Ft. Pierce, Florida 33450, USA
}

\begin{abstract}
The influence of macrophyte biomass and species composition on the distribution of macrobenthic crustaceans was examined in 2 vegetated and 2 unvegetated grass bed microhabitats under similar physical-chemical conditions. Vegetated habitats consistently supported higher numbers of individuals and species than either of the unvegetated zones. Correlations between plant biomass in each microhabitat and both animal numbers and diversity suggested that seagrass biomass was a key organizing factor in macrophyte-associated faunal assemblages. The thin-bladed Halodule wrightii supported similar crustacean abundance per core, density and species richness to those found on widebladed Thalassia testudinum, contradicting the predictions of Kikuchi and Pérès (1977) that widebladed magnozosterids should have a more abundant and diverse fauna relative to thin-bladed parvozosterids. In addition, after standardization to numbers of individuals per unit plant biomass (or surface area), $H$. wrightii supported higher abundance than $T$. testudinum suggesting that seagrass species composition is more important to faunal organization than previously thought. Although similar suites of species inhabited each substratum, relative abundances of individual species were markedly different among the microhabitats. Greatest differences occurred between vegetated and unvegetated zones. Few of the 24 dominant crustaceans (those species with abundances of $1 \%$ or more of the total number of individuals collected) had significantly greater abundances per core on one seagrass species relative to the other. Three species were more abundant on $T$. testudinum while only 1 occurred in greater numbers on $H$. wrightii. However, when species abundances per unit plant weight (or surface area) were compared between the 2 vegetation forms, 7 species were significantly more abundant on $H$. wrightii; only 2 species occurred in higher numbers on $T$. testudinum. Distribution of crustaceans among seagrass microhabitats appeared to be a complex function involving faunal habitat choice and predation pressure, both of which are affected by the species and biomass of seagrass present.
\end{abstract}

\section{INTRODUCTION}

Relations between habitat complexity and faunal species richness and abundance are incompletely understood in vegetated marine environments. Generally, an increase in habitat complexity is correlated with an increase in both abundance and diversity, yet uncertainty remains as to what aspects of the environment contribute to increasing complexity. In coastal seagrass meadows, macrophytes are certainly the most conspicuous component of the environment; intuitively, they should be a major factor contributing to habitat complexity.

Investigations of grass bed complexity have concen-

Contribution No. 381 of the Harbor Branch Foundation, Inc. trated on various aspects of the plant assemblage present, including biomass (Orth, 1973, 1977; Heck and Wetstone, 1977; Heck and Orth, 1980a; Stoner, 1980a), shoot density (Brook, 1978), surface area (Stoner, 1983) and species composition (Ledoyer, 1962; O'Gower and Wacasey, 1967; Santos and Simon, 1974; Martin and Cooper, 1981; Young, 1981; Stoner, 1983). The relative contribution of each of these factors to total complexity (and ultimately to faunal organization) is not easily separable. Often, environmental variables unrelated to macrophytes co-occur, obscuring the effects of vegetation alone (Ledoyer, 1962; O'Gower and Wacasey, 1967; Brook, 1978).

Seagrasses in the northern Gulf of Mexico exhibit a variety of morphologies. Using the classification of den Hartog (1967), these growth forms may be divided into 
several categories, including: magnozosterids (e.g. Thalassia testudinum) with wide, linear blades, and parvozosterids (e.g. Halodule wrightin) with fine, linear blades. Because of their large leaf areas which provide both a shading effect and high microhabitat diversity, Kikuchi and Pérès (1977) hypothesized that magnozosterids should support greater faunal diversity and biomass than parvozosterids.

In the present study I examine the role of vegetation, including both seagrass species composition and biomass, in the organization of associated crustacean faunas. Crustacean assemblages of 2 dominant seagrasses, Thalassia testudinum (a magnozosterid) and Halodule wrightii (a parvozosterid), were compared to test the hypothesis of Kikuchi and Pérès (1977). Macrophyte associates were also compared with the faunas of 2 unvegetated areas to assess the influence of seagrass biomass in structuring grass bed macrofauna (Heck and Wetstone, 1977; Stoner, 1980a). Collections were examined from closely adjacent substrata to eliminate problems of dissimilar physical conditions encountered in other studies.

\section{METHODS}

Study site. The study site was located in Apalachee Bay, a shallow estuarine area in the Big Bend of Florida, northeastern Gulf of Mexico $\left(30^{\circ} \mathrm{N}, 83^{\circ} 55^{\prime} \mathrm{W}\right)$. Its coastal waters support luxuriant seagrass meadows extending up to $35 \mathrm{~km}$ off-shore (Bittaker and Iverson, in press). Within this area, 2 estuaries and adjacent grass beds (Econfina and Fenholloway Rivers) have been the focus of extensive investigations, including studies of benthic macrophytes (Zimmerman and Livingston, 1976, 1979), macrobenthic invertebrates (Heck, 1976; Hooks et al., 1976; Stoner, 1980a, b; Lewis and Stoner, 1981, 1983; Dugan and Livingston, 1982; Greening and Livingston, 1982) and fishes (Livingston, 1975, 1982; Stoner, 1980d; Ryan, 1981; Stoner and Livingston, 1981; Clements and Livingston, 1983). Detailed descriptions of sampling stations are found in these works; a brief account of the area follows below.

The present study was conducted at a site approximately $5 \mathrm{~km}$ southwest of the mouth of the Econfina River (permanent sampling station Econfina 12; Livingston, 1975). The area was polyhaline with salinities ranging from 16 to $30 \%$. Water temperatures ranged from $12.0^{\circ} \mathrm{C}$ in Dec 1979 to $32.0^{\circ} \mathrm{C}$ in Jul 1980 .

These coastal grass beds support a heterogeneous mixture of seagrasses (primarily Thalassia testudinum, Halodule wrightii, Syringodium filiforme) and macroalgae, with scattered monotypic stands of seagrass and variously-sized bare patches. Mean above-ground macrophyte biomass was $287.4 \mathrm{~g}$ dry $\mathrm{wt}^{-2}$ (Lewis,
1982). $T$. testudinum dominated the macrophyte assemblage, comprising $80.4 \%$ of the total biomass at the site. A small area was selected for detailed microhabitat study where a large irregularly-shaped bare sand patch ( 5 by $10 \mathrm{~m}$ ), surrounded by a zone of $H$. wrightii (ranging in width from 0.5 to $4.0 \mathrm{~m}$ ), occurred within a dense $T$. testudinum bed.

Sampling methods. Benthic crustaceans were collected from each of 4 substrata: dense vegetation stands of Thalassia testudinum and Halodule wrightii, small sandy areas among $T$. testudinum shoots, and a large bare sand patch. Collections were made in Sep 1979 and May and Sep 1980, corresponding with periods of low (Sep) and high (May) crustacean abundance and species richness (Stoner, 1980a, b). Diveroperated, hand-held cores made of short sections of PVC pipe (5.1 cm inside diameter; $\left.20.4 \mathrm{~cm}^{2}\right)$ were used for all sampling. Lewis and Stoner (1981) examined the relative effectiveness of 3 different-sized coring devices and showed that this smallest sampling device collected a significantly greater number of individuals of grass bed fauna than either of the larger corers tested ( 7.6 and $10.5 \mathrm{~cm}$ diameters) when equal sediment surface areas were compared. Cores were taken to a depth of $10 \mathrm{~cm}$ as initial investigations (Stoner, 1980 a) showed that $98 \%$ of the macrofauna is found in the top $5 \mathrm{~cm}$ of sediment.

Twenty replicate cores were examined from each substratum per sampling date. Because of the spatial arrangement of Thalassia testudinum shoots, each sample included only one shoot (bundle sheath and blades). During sampling, the corer was slowly lowered over an individual shoot while the blades were gently manipulated into the sampler. Because of the dense spatial distribution of Halodule wrightii, numerous shoots were sampled in each core.

Core samples were sieved in the field through a $0.5 \mathrm{~mm}$ mesh screen (see recommendations of Lewis and Stoner, 1981), stained with rose bengal and preserved in $10 \%$ buffered Formalin. All animals were hand-sorted in the laboratory and the crustaceans were identified to the lowest possible taxon. All plant material (alive or dead) was removed from each core and the above- and below-ground parts were dried $\left(100^{\circ} \mathrm{C}\right.$ for $48 \mathrm{~h}$ ) separately. Epiphytic and drift algae, when present, were included in the above-ground category.

Abundances of seagrass-associated crustaceans are reported either as number of individuals per core, number per $g$ dry weight of plant material, or number per $\mathrm{m}^{2}$ (density). Densities of animals associated with the two vegetation types were estimated by multiplying the number of individuals per $g$ dry weight of plant material by the biomass of seagrass ( $\mathrm{g}$ dry weight $\mathrm{m}^{-2}$ ) present. Biomass for Thalassia testudinum and Halodule wrightii were obtained using a repetitive quadrat 
technique (Livingston et al., 1976) with 8 replicates substratum $^{-1}$ date $^{-1}$. Crustacean species richness is reported as number of species core ${ }^{-1}$.

Statistical analysis. Since both parametric and nonparametric analyses yielded identical results, only parametric results are presented. Log-transformed data were used in all ANOVAs to satisfy the equal variance assumption of the model. No significant interactions appeared in any ANOVA; hence, only results for main effects of substrata or dates are given. Tukey's honestly significant difference test (HSD) was used to compare substrata from each of the sampling dates.

Abundances of individual crustacean species were compared between vegetated and unvegetated substrata, and between Halodule wrightii and Thalassia testudinum using $t$-tests. In cases where numerous repetitive tests are performed, the Bonferroni approximation is often used to set the alpha value and control the family-wide error rate (Myers, 1979). However, this approximation may result in a conservative assessment of significance, especially if a large number of tests are carried out. In the present study, the Bonferroni approximation was not used; an alpha level of 0.01 indicated a statistically significant response. Results of comparisons with error probabilities between 0.05 and 0.01 were considered as suggestive of a relationship.

Species composition and relative abundance of crustaceans were analyzed with the similarity index ' $r$ ho' (Matusita, 1955; van Belle and Ahmad, 1974). This index was chosen because of its concentration on the proportion of the total number of individuals represented by each species in the compared populations (or samples). In comparison of collections with large differences in total number of individuals, simi- larity indices that examine absolute differences in the number of individuals of each species between samples appear inappropriate. Similarity coefficients were incorporated into a clustering strategy based on a flexible grouping method with beta $=-0.25$ (Lance and Williams, 1967; Meeter and Livingston, 1978).

\section{RESULTS}

Measurements of temperature, salinity, depth and sediment grain size, taken concurrently with biological sampling, indicated that all substrata were similar (ANOVA; $\mathrm{P}>0.10$ ) except for the amount of vegetation present (ANOVA; $P<0.05$ ) (Table 1). Aboveground macrophyte biomass varied significantly among the substrata, from zero in the large bare patch to a mean of $228.3 \mathrm{~g}$ dry $\mathrm{wt} \mathrm{m}^{-2}$ for Thalassia testudinum. Small quantities of $T$. testudinum detritus and algae were observed on the small sandy areas among $T$. testudinum shoots yielding an estimate of $33.7 \mathrm{~g}$ dry wt $\mathrm{m}^{-2}$ for this microhabitat. Live-plant biomass was lowest in May for both seagrass substrata while highest amounts of plant debris occurred during this month among $T$. testudinum shoots. This accumulation of detrital material may have originated from winter seagrass defoliation. Below-ground seagrass biomass varied significantly over the substrata as well, ranging from zero in the bare patch to a mean of $512.5 \mathrm{~g}$ dry wt $\mathrm{m}^{-2}$ for $T$. testudinum. As expected, large quantities of root and rhizome material $(\bar{X}=$ $375.6 \mathrm{~g}$ dry $w \mathrm{~m}^{-2}$ ) occurred in the sandy areas among $T$. testudinum shoots, amounting to almost $75 \%$ of that found close to the shoots. Below-ground biomass from

Table 1. Environmental conditions recorded from the 4 grass bed substrata on 3 sampling dates. Values for grain size and macrophyte biomass are means $( \pm \mathrm{SD})$ with $\mathrm{n}=3$ and 8 , respectively

\begin{tabular}{|c|c|c|c|c|c|c|}
\hline Substrata & $\begin{array}{l}\text { Temperature } \\
\left({ }^{\circ} \mathrm{C}\right)\end{array}$ & $\begin{array}{l}\text { Salinity } \\
(\% \infty)\end{array}$ & $\begin{array}{l}\text { Depth } \\
\text { (m) }\end{array}$ & $\begin{array}{l}\text { Grain size } \\
\quad(\mathrm{mm})\end{array}$ & $\frac{\text { Macrophyte biomass }}{\text { Above-ground }}$ & $\frac{\text { (g dry wt } \mathrm{m}^{-2} \text { ) }}{\text { Below-ground }}$ \\
\hline \multicolumn{7}{|l|}{ Sep 1979} \\
\hline Bare & 22.5 & 25.0 & 1.8 & $0.25(0.02)$ & 0.0 & 0.0 \\
\hline Among Thalassia & 22.5 & 25.0 & 1.7 & $0.23(0.03)$ & $19.3 \quad(4.3)$ & $376.1(160.0)$ \\
\hline Halodule & 22.5 & 25.0 & 1.7 & $0.22(0.03)$ & $92.8(13.6)$ & $163.8(77.6)$ \\
\hline Thalassia & 22.5 & 25.0 & 1.7 & $0.22(0.02)$ & $256.6(31.3)$ & $543.5(178.2)$ \\
\hline \multicolumn{7}{|l|}{ May 1980} \\
\hline Bare & 27.0 & 22.0 & 2.4 & $0.26(0.02)$ & 0.0 & 0.0 \\
\hline Among Thalassia & 27.0 & 22.0 & 2.4 & $0.25(0.01)$ & $56.3(8.3)$ & $455.9(219.3)$ \\
\hline Halodule & 27.0 & 22.0 & 2.4 & $0.24(0.03)$ & $77.5(12.5)$ & $155.8(60.1)$ \\
\hline Thalassia & 27.0 & 22.0 & 2.4 & $0.25(0.03)$ & $204.9(39.7)$ & $478.5(104.4)$ \\
\hline \multicolumn{7}{|l|}{ Sep 1980} \\
\hline Bare & 28.5 & 22.0 & 2.2 & $0.24(0.02)$ & 0.0 & 0.0 \\
\hline Among Thalassia & 28.5 & 22.0 & 2.1 & $0.25(0.01)$ & $25.6 \quad(7.5)$ & $294.7(124.5)$ \\
\hline Halodule & 28.5 & 22.0 & 2.2 & $0.23(0.04)$ & $89.2 \quad(9.8)$ & $151.7 \quad(42.8)$ \\
\hline Thalassia & 28.5 & 22.0 & 2.1 & $0.24(0.01)$ & $223.3(35.6)$ & $515.6(167.3)$ \\
\hline
\end{tabular}


Table 2. Total and relative abundances of the crustacean fauna collected from 4 microhabitats (a large bare patch, sandy areas among Thalassia testudinum shoots, Halodule wrightii and $T$. testudinum shoots) within the Apalachee Bay grass bed. Miscellaneous taxa are: $\mathrm{C}=$ cephalocarid, $\mathrm{I}=$ isopod, $\mathrm{M}=$ mysid, $\mathrm{P}=$ pycnogonid, $\mathrm{T}=\operatorname{tanaid}$

\begin{tabular}{|c|c|c|c|c|c|c|c|c|}
\hline \multirow[t]{2}{*}{ Species } & \multicolumn{2}{|c|}{ Bare } & \multicolumn{2}{|c|}{ Among Thalassia } & \multicolumn{2}{|c|}{ Halodule } & \multicolumn{2}{|c|}{ Thalassia } \\
\hline & Number & $\%$ & Number & $\%$ & Number & $\%$ & Number & $\%$ \\
\hline \multicolumn{9}{|l|}{ Amphipoda } \\
\hline Lembos unifasciatus & 7 & 13.2 & 39 & 14.4 & 84 & 10.6 & 215 & 18.4 \\
\hline Erichthonius brasiliensis & & & 16 & 5.9 & 69 & 8.7 & 89 & 7.6 \\
\hline Lysianassa alba & & & 15 & 5.6 & 57 & 7.2 & 80 & 6.9 \\
\hline Rudilemboides naglei & 3 & 5.7 & 39 & 14.4 & 55 & 7.0 & 53 & 4.6 \\
\hline Cymadusa compta & & & 12 & 4.4 & 50 & 6.3 & 81 & 7.0 \\
\hline Tethygeneia longleyi & 4 & 7.6 & 5 & 1.8 & 42 & 5.3 & 83 & 7.1 \\
\hline Elasmopus levis & & & 9 & 3.3 & 15 & 1.9 & 107 & 9.2 \\
\hline Ampelisca vadorum & & & 6 & 2.2 & 52 & 6.6 & 54 & 4.6 \\
\hline Luconacia incerta & & & 2 & 0.7 & 73 & 9.2 & 35 & 3.0 \\
\hline Cerapus sp. (cf. tubularis) & & & 8 & 3.0 & 36 & 4.6 & 37 & 3.2 \\
\hline Ampithoe longimana & & & 2 & 0.7 & 19 & 2.4 & 39 & 3.3 \\
\hline Lembos rectangulatus & & & 11 & 4.1 & 13 & 1.6 & 24 & 2.1 \\
\hline Ampelisca verrilli & 3 & 5.7 & 23 & 8.5 & 10 & 1.3 & 7 & 0.6 \\
\hline Batea catharinensis & 3 & 5.7 & 1 & 0.4 & 27 & 3.4 & 10 & 0.9 \\
\hline Carinobatea carinata & 1 & 1.9 & 6 & 2.2 & 9 & 1.1 & 24 & 2.1 \\
\hline Photis macromanus & & & 1 & 0.4 & 5 & 0.6 & 34 & 2.9 \\
\hline Gitanopsis tortugae & 2 & 3.8 & 2 & 0.7 & 5 & 0.6 & 24 & 2.1 \\
\hline Grandidierella bonnieroides & & & 5 & 1.8 & 16 & 2.0 & 5 & 0.4 \\
\hline Synchelidium americanum & 2 & 3.8 & 10 & 3.7 & 3 & 0.4 & 3 & 0.3 \\
\hline Listriella barnardi & & & 6 & 2.2 & & & 2 & 0.2 \\
\hline Melita appendiculata & & & 2 & 0.7 & & & 5 & 0.4 \\
\hline Erichthonius sp. (cf. rubricornis) & & & & & 1 & 0.1 & 5 & 0.4 \\
\hline Stenothoe minuta & & & 1 & 0.4 & & & 3 & 0.3 \\
\hline Lembos smithi & & & & & 2 & 0.2 & 2 & 0.2 \\
\hline Paraphoxus spinosus & & & 2 & 0.7 & & & 1 & 0.1 \\
\hline Lembos unicornis & 1 & 1.9 & & & 1 & 0.1 & & \\
\hline Microdeutopus myersi & & & & & 1 & 0.1 & 1 & 0.1 \\
\hline Monoculodes sp. (cf. nyer) & 2 & 3.8 & & & & & & \\
\hline Gammarus muctonatus & & & & & 1 & 0.1 & & \\
\hline Corophium simile & & & & & 1 & 0.1 & & \\
\hline Microprotopus raneyi & & & & & & & 1 & 0.1 \\
\hline No. of individuals & 28 & 52.8 & 223 & 82.6 & 647 & 81.8 & 1024 & 87.8 \\
\hline No. of species & 10 & 52.6 & 23 & 59.0 & 25 & 50.0 & 27 & 55.1 \\
\hline \multicolumn{9}{|l|}{ Decapoda } \\
\hline Pagurus maclaughlinae & 2 & 3.8 & 1 & 0.4 & 18 & 2.3 & 21 & 1.8 \\
\hline Hippolyte zostericola & & & 9 & 3.3 & 1 & 0.1 & 12 & 1.0 \\
\hline Pelia mutica & & & & & 7 & 0.9 & 8 & 0.7 \\
\hline Ambidexter symmetricus & 3 & 5.7 & 1 & 0.4 & 4 & 0.5 & 3 & 0.3 \\
\hline Pinnixa sp. (cf. chacel) & & & 5 & 1.8 & 3 & 0.4 & 2 & 0.2 \\
\hline Processa bermudensis & & & & & & & 8 & 0.7 \\
\hline Latreutes fucorum & & & 2 & 0.7 & 1 & 0.1 & 3 & 0.3 \\
\hline Alpheus normanni & & & & & 5 & 0.6 & 1 & 0.1 \\
\hline Thor dobkini & & & & & 1 & 0.1 & 4 & 0.3 \\
\hline Epialtus dilatatus & & & & & 1 & 0.1 & 3 & 0.3 \\
\hline Callianassa sp. & 3 & 5.7 & & & & & & \\
\hline Neopanope texana & & & & & 2 & 0.2 & 1 & 0.1 \\
\hline Periclimenes longicaudatus & & & 1 & 0.4 & 1 & 0.1 & & \\
\hline Podochela riisei & & & & & 1 & 0.1 & 1 & 0.1 \\
\hline Penaeus duorarum & & & 2 & 0.7 & & & & \\
\hline Processa vicina & & & & & & & 1 & 0.1 \\
\hline Pinnotheres sp. & & & & & 1 & 0.1 & & \\
\hline Ogyrides limicola & & & & & 1 & 0.1 & & \\
\hline Pitho anisodon & & & & & 1 & 0.1 & & \\
\hline No, of individuals & 8 & 15.1 & 21 & 7.8 & 48 & 6.1 & 68 & 5.8 \\
\hline No. of species & 3 & 15.8 & 7 & 17.9 & 15 & 30.0 & 13 & 26.5 \\
\hline
\end{tabular}


Table 2. Continued

\begin{tabular}{|c|c|c|c|c|c|c|c|c|}
\hline \multirow[t]{2}{*}{ Species } & \multicolumn{2}{|c|}{ Bare } & \multicolumn{2}{|c|}{ Among Thalassia } & \multicolumn{2}{|c|}{ Halodule } & \multicolumn{2}{|c|}{ Thalassia } \\
\hline & Number & $\%$ & Number & $\%$ & Number & $\%$ & Number & $\%$ \\
\hline \multicolumn{9}{|l|}{ Miscellaneous Taxa } \\
\hline Erichsonella filiformis (I) & 1 & 1.9 & 3 & 1.1 & 57 & 7.2 & 4 & 0.3 \\
\hline Hargeria rapax $(\mathrm{T})$ & & & 1 & 0.4 & 9 & 1.1 & 24 & 2.1 \\
\hline Paracerceis caudata (I) & 2 & 3.8 & 1 & 0.4 & 7 & 0.9 & 14 & 1.2 \\
\hline Cumacean spp. & 3 & 5.7 & 5 & 1.8 & 6 & 0.8 & 10 & 0.9 \\
\hline Bowmaniella brasiliensis (M) & 9 & 17.0 & 9 & 3.3 & & & & \\
\hline Lightiella floridana (C) & 1 & 1.9 & 4 & 1.5 & 4 & 0.5 & 8 & 0.7 \\
\hline Cyathura polita (I) & 1 & 1.9 & 1 & 0.4 & 3 & 0.4 & 2 & 0.2 \\
\hline Bowmaniella dissimilis (M) & & & & & & & 7 & 0.6 \\
\hline Edotea montosa (I) & & & & & 3 & 0.4 & 3 & 0.3 \\
\hline Apseudes sp. (T) & & & 1 & 0.4 & 3 & 0.4 & & \\
\hline Cleantis planicauda (I) & & & & & 3 & 0.4 & & \\
\hline Mysidopsis furca (M) & & & & & & & 2 & 0.2 \\
\hline Mysidopsis almyra (M) & & & & & 1 & 0.1 & & \\
\hline Anoplodactylus insignis (P) & & & 1 & 0.4 & & & & \\
\hline No. of individuals & 17 & 32.1 & 26 & 9.6 & 96 & 12.1 & 74 & 6.3 \\
\hline No. of species & 6 & 31.6 & 9 & 23.1 & 10 & 20.0 & 9 & 18.4 \\
\hline Total no. of individuals & 53 & & 270 & & 791 & & 1166 & \\
\hline Total no. of species & 19 & & 39 & & 50 & & 49 & \\
\hline
\end{tabular}

Halodule wrightii ( $\overline{\mathrm{X}}=157.1 \mathrm{~g}$ dry $\mathrm{wt}^{-2}$ ) was consistently lower than that in $T$. testudinum.

Sixty-four crustacean species (31 amphipods, 19 decapods, 14 miscellaneous taxa) were collected from the 240 core samples (Table 2). Numbers of species core $^{-1}$, numbers of individuals core ${ }^{-1}$, and densities differed significantly among the 4 substrata (2-way ANOVA; $\mathrm{p}<0.01$ ) (Table 3; Fig. 1). Although values were highest for all measures from the Thalassia testudinum substratum (with 1 exception, May density), monthly values for the 2 vegetation types were not significantly different because of high variability among samples from each substratum (Tukey's HSD; $\mathrm{p}>0.05$ ). However, both vegetated microhabitats always had significantly higher values than either of the unvegetated substrata. The large bare patch supported lowest abundance, species richness and density while intermediate values of each were found in the small sandy areas among $T$. testudinum shoots (Tukey's HSD; $\mathrm{p}<0.05$ ). Seasonal trends were similar for all measures with highest values recorded in May (Fig. 1) for all substrata. Above-ground plant biomass correlated significantly with numbers of species (Pearson's $r=0.810 ; p<0.01$ ), numbers of individuals core $^{-1}$ (Pearson's $r=0.790 ; p<0.01$ ) and individuals $\mathrm{m}^{-2}$ (Pearson's $\mathrm{r}=0.730 ; \mathrm{p}<0.01$ ) over the 4 seagrass microhabitats.

Despite sampling equal bottom surface area in each microhabitat, the amount of plant material collected per sample varied with substratum because of the

Table 3. Mean values for numbers of individuals and species compared over the 4 grass bed substrata (underlined values: no significant difference in means; ANOVA and Tukey's HSD; $>>0.05$ )

\begin{tabular}{|c|c|c|c|c|}
\hline & \multicolumn{4}{|c|}{ Substrata } \\
\hline & Bare & $\begin{array}{l}\text { Among } \\
\text { Thalassia }\end{array}$ & Halodule & Thalassia \\
\hline Individuals core ${ }^{-1}$ & 0.88 & 4.50 & 13.18 & 19.43 \\
\hline Individuals $\mathrm{m}^{-2}$ & 432 & 2203 & 6453 & 6978 \\
\hline Individuals $\mathrm{g}^{-1} \mathrm{dry}$ plant wt & - & 64.26 & 76.43 & 29.48 \\
\hline Individuals $100 \mathrm{~cm}^{-2}$ plant surface area & - & - & 10.71 & 5.73 \\
\hline Number of species core $e^{-1}$ & 0.75 & 2.67 & 7.20 & 8.87 \\
\hline
\end{tabular}




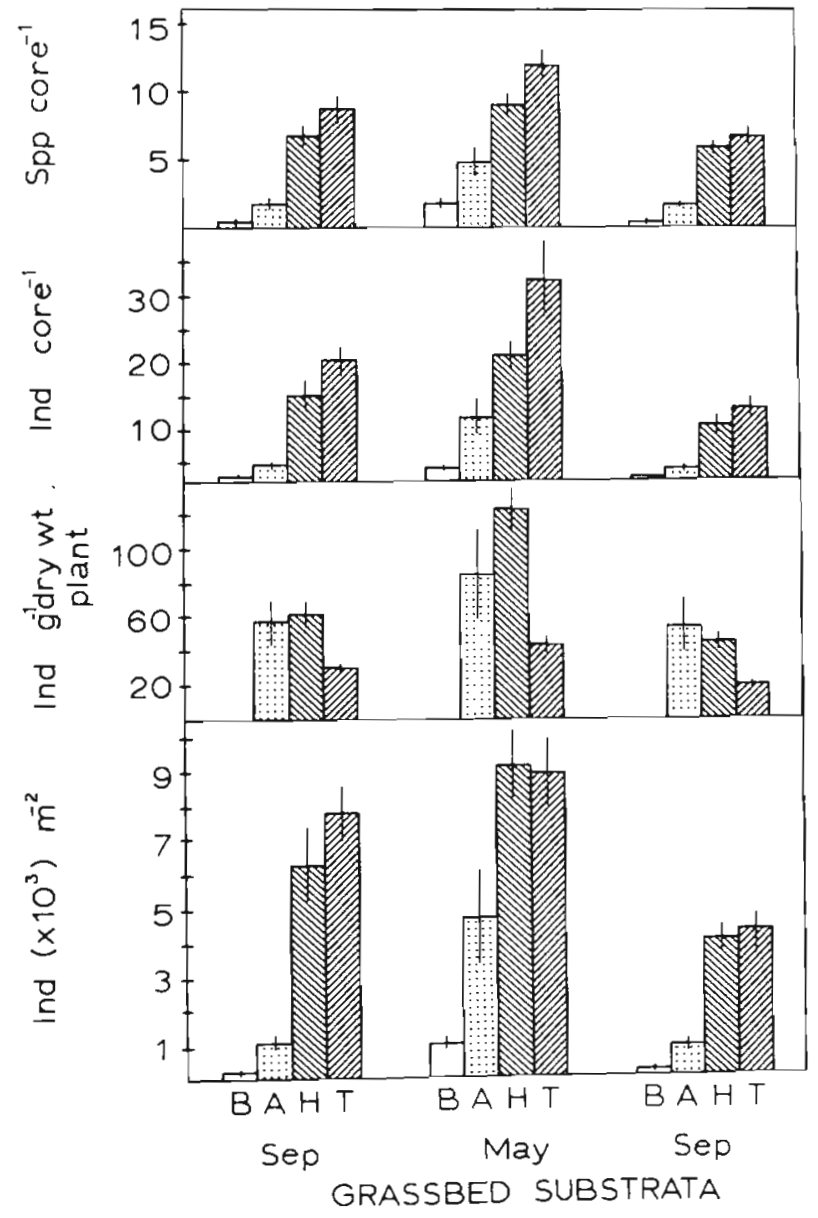

Fig. 1. Comparison of crustacean abundance and species richness from 4 grass bed microhabitats ( $B$ : large bare patch, A: sandy areas among Thalassia testudinum shoots, $\mathrm{H}$ : Halodule wrightii shoots, $\mathrm{T}: T$. testudinum shoots). Vertical lines indicate $\pm \mathrm{SE}$ about the monthly mean

morphology and spatial distribution of the seagrasses. This is reflected in the total macrophyte biomass present in each microhabitat (Table 1). To account for this difference, abundances of animals in the $3 \mathrm{mi}$ crohabitats containing some form of vegetation (either living or dead) were compared after standardizing to abundance per weight of plant matter (Fig. 1). Crustacean abundances per plant weight were significantly different among the substrata (2-way ANOVA; $\mathrm{p}<0.01$; Table 3). While the seasonal trend in the abundance per plant weight was similar to that of the previous measures (with highest values in May), the order of abundance within months was different. Unexpectedly, numbers of crustaceans associated with Halodule wrightii ( $\overline{\mathrm{X}}=76.4$ ind $\mathrm{g}$ dry $\mathrm{wt}^{-1}$ ) were not significantly different from those found in the sandy areas among Thalassia testudinum shoots $(\overline{\mathrm{X}}=64.3$ ind $g$ dry $w^{-1}$ ) (Tukey's HSD; $p>0.05$ ) but were significantly greater than abundances from $T$. testudinum shoots $\left(\overline{\mathrm{X}}=29.5\right.$ ind $\left.\mathrm{g}_{\mathrm{dry}} \mathrm{wt}^{-1}\right)$. Unlike the previous measures of abundance, number of crustaceans per plant weight was unrelated to macrophyte biomass (Pearson's $\mathrm{r}=-0.481 ; \mathrm{P}>0.05$ ).

Experimental studies (Stoner, 1980c) indicate that some epifaunal amphipods select seagrass microhabitats based on blade surface area rather than biomass. Using Stoner's surface area to biomass conversion ratios for Halodule wrightii $\left(715 \mathrm{~cm}^{2} \mathrm{~g}\right.$ dry $\left.\mathrm{wt}^{-1}\right)$ and Thalassia testudinum $\left(515 \mathrm{~cm}^{2} \mathrm{~g} \mathrm{dry} \mathrm{wt}^{-1}\right)$, numbers of crustaceans were compared for the 2 vegetated substrata. As with abundance per plant weight, numbers of individuals per plant surface area were significantly higher on $H$. wrightii $(\overline{\mathrm{X}}=10.7$ ind $\left.100 \mathrm{~cm}^{-2}\right)$ than $T$. testudinum $\left(\overrightarrow{\mathrm{X}}=5.7\right.$ ind $\left.100 \mathrm{~cm}^{-2}\right)$ during the sampling months ( $t$-test; $p<0.05$ ).

Because of these significant differences in the number of individuals collected per substratum, and the strong relation between numbers of individuals and species (Pearson's $r=0.893 ; p<0.001$ ), rarefaction curves were generated for expected numbers of species using the technique of Heck et al. (1975) and Simberloff (1978). Comparison of these curves (Table 4) indicated that similar-sized samples drawn at random from each microhabitat yielded similar numbers of species. Hence, differences in species richness among the grass bed substrata resulted primarily from differences in animal abundance.

Based on Bousfield (1973) for amphipods, Williams (1965) and Abele (1970) for decapods, and various life history studies for the miscellaneous taxa, all crustaceans in this study were categorized as (1) epifaunal free-living, (2) epifaunal domicolous, (3) infaunal freeliving, (4) infaunal tubicolous or (5) commensal. Comparing infaunal and epifaunal components over the grass bed substrata, the percent epifauna increased with increasing amounts of seagrass biomass (Table 5). Yet, despite pronounced differences in the amounts of seagrass present (Table 1), both vegetated substrata displayed similar percentages of epifauna. Proportions of epifaunal free-living forms were highest on vegetated substrata, while percentages of epifaunal domicolous forms were highest from sandy areas among Thalassia testudinum shoots which contained only small amounts of plant debris. Densities of epifaunal crustaceans correlated significantly with aboveground seagrass biomass (Pearson's $r=0.744$;

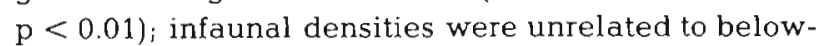
ground biomass (Pearson's $r=0.386 ; \mathrm{p}>0.10$ ).

In a comparison of species composition and relative abundance among the 4 microhabitats using the similarity coefficient 'Tho' (Fig. 2), faunas associated with Halodule wrightii and Thalassia testudinum were most similar ('rho' $=0.904$ ). Crustaceans associated with small bare areas among $T$. testudinum shoots were similar to those found in both vegetated zone ('rho' = 
Table 4 . Comparison of rarefaction curves for the 4 grass bed microhabitats (a large bare patch, sandy areas among Thalassia testudinum shoots, Halodule wrightii and $T$. testudinum shoots). Expected numbers of species (with variance in parentheses for expected number) for smaller subsamples from each substratum.

\begin{tabular}{|c|c|c|c|c|}
\hline $\begin{array}{l}\text { Number of } \\
\text { individuals }\end{array}$ & Bare & $\begin{array}{l}\text { Among } \\
\text { Thalassia }\end{array}$ & Halodule & Thalassia \\
\hline 10 & $7.7(1.2)$ & $7.7(1.4)$ & $7.8(1.2)$ & $7.5(1.4)$ \\
\hline 30 & $15.4(1.7)$ & $16.1(3.8)$ & $15.6(3.6)$ & $15.2(3.7)$ \\
\hline 53 & $19.0(0.0)$ & $21.7(4.6)$ & $20.3(4.7)$ & $20.0(4.7)$ \\
\hline 100 & & $28.2(4.5)$ & $26.0(5.6)$ & $25.8(5.5)$ \\
\hline 200 & & $35.6(2.4)$ & $33.0(5.7)$ & $32.5(5.7)$ \\
\hline 270 & & $39.0(0.0)$ & $36.3(5.4)$ & $35.9(5.4)$ \\
\hline 500 & & & $43.2(3.7)$ & $41.8(4.0)$ \\
\hline 791 & & & $50.0(0.0)$ & $46.0(2.2)$ \\
\hline 1166 & & & & $49.0(0.0)$ \\
\hline
\end{tabular}

Table 5. Comparison of infaunal and epifaunal crustacean categories. Percentage of total individuals in each category collected for each microhabitat (a large bare patch, sandy areas among Thalassia testudinum shoots, Halodule wrightii and $T$ testadinum shoots)

\begin{tabular}{|lrrrr|}
\hline & \multicolumn{4}{c|}{ Substrata } \\
Microhabitat & Bare & $\begin{array}{c}\text { Among } \\
\text { Thalassia }\end{array}$ & Halo- & Tha- \\
duste & lassia \\
\hline Infaunal tubicolous & 13.2 & 11.1 & 8.3 & 5.5 \\
Infaunal free-living & 37.7 & 21.1 & 12.8 & 15.8 \\
Infaunal commensal & 0.0 & 1.8 & 0.5 & 0.2 \\
Epifaunal domicolous & 20.8 & 48.9 & 43.9 & 47.3 \\
Epifaunal free-living & 28.3 & 17.0 & 34.5 & 31.3 \\
& & & & \\
Total infauna & 50.9 & 34.1 & 21.6 & 21.4 \\
Total epifauna & 49.1 & 65.9 & 78.4 & 78.6 \\
\hline
\end{tabular}

0.807). The composition of fauna occurring in the large bare area was distinct from that of the other microhabitats ('rho' $=0.424$ ).

Relative proportions of several species (Table 2 and shown in histogram form for those species comprising $4 \%$ or more of the fauna for each substratum in Fig. 2), varied strikingly among the 4 microhabitats. Monoculodes sp. and Callianassa sp., both infaunal burrowers, were present only in the large bare area. Sandy areas among Thalassia testudinum shoots yielded highest numbers of the burrowing amphipods Ampelisca verrilli, Synchelidium americanum and Listriella barnardi as well as the shrimp Penaeus duorarum. One mysid, Bowmaniella brasiliensis, occurred only in unvegetated patches, while others, $B$. dissimilis, Mysidopsis furca and M. almyra, were present only in close association with seagrasses. Vegetated areas supported highest abundances of all epifaunal species (except the pycnogonid Anoplodactylus insignis) as well as some numerically abundant infaunal species (e.g. Lysianassa alba and Ampelisca vadorum).
Of the 24 numerically dominant species (each accounting for $1 \%$ or more of the total number of individuals collected over all substrata), all but 5 occurred in significantly greater abundance in the vegetated zones ( $t$-tests, one-tailedi $p<0.01$ ) (Table 6). Abundances of 2 amphipods, Lembos rectangulatus and Lysianassa alba, were marginally greater in vegetated compared to unvegetated areas $(0.01<\mathrm{p}$ $<0.05)$. Only Ampelisca verrilli, Hippolyte zostericola and the cumaceans were as abundant in unvegetated as in vegetated microhabitats ( $t$-tests; $\mathrm{p}>0.05$ ).

Comparing the 2 vegetated habitats, 3 species had significantly higher abundances per core in Thalassia testudinum while only 1 species was more abundant in Halodule wrightii (t-tests, 2-tailed; p < 0.01) (Table 6). The amphipods Elasmopus levis, Gitanopsis tortugae and Lembos unifasciatus were found in greater abundance on $T$. testudinum. Only the isopod Erichsonella filiformis was present in significantly higher abundance associated with $H$. wrightii. Ten other species had abundances per core that were marginally indicative of a specific substratum association $0.01<$ $\mathrm{p}<0.05$ ). Those species associated with $T$. testudinum included the amphipods Ampithoe longimana, Carinobatea carinata, Cymadusa compta, Photis macromanus and Tethygeneia longleyi, the decapod shrimp Hippolyte zostericola and the tanaid Hargeria rapax; the amphipods Batea catharinensis, Grandidierella bonnieroides and Luconacia incerta were associated with $H$. wrightii.

To account for potential abundance differences caused by different amounts of seagrass in each vegetated microhabitat, the dominant crustaceans were compared after standardizing to abundances per unit plant weight and per unit plant surface area. The 4 infaunal taxa, Ampelisca vadorum, $A$. verrilli, Lysianassa alba and the cumaceans, were not included in this analysis; these species reside in the sediments around the plant bases and presumably are less 


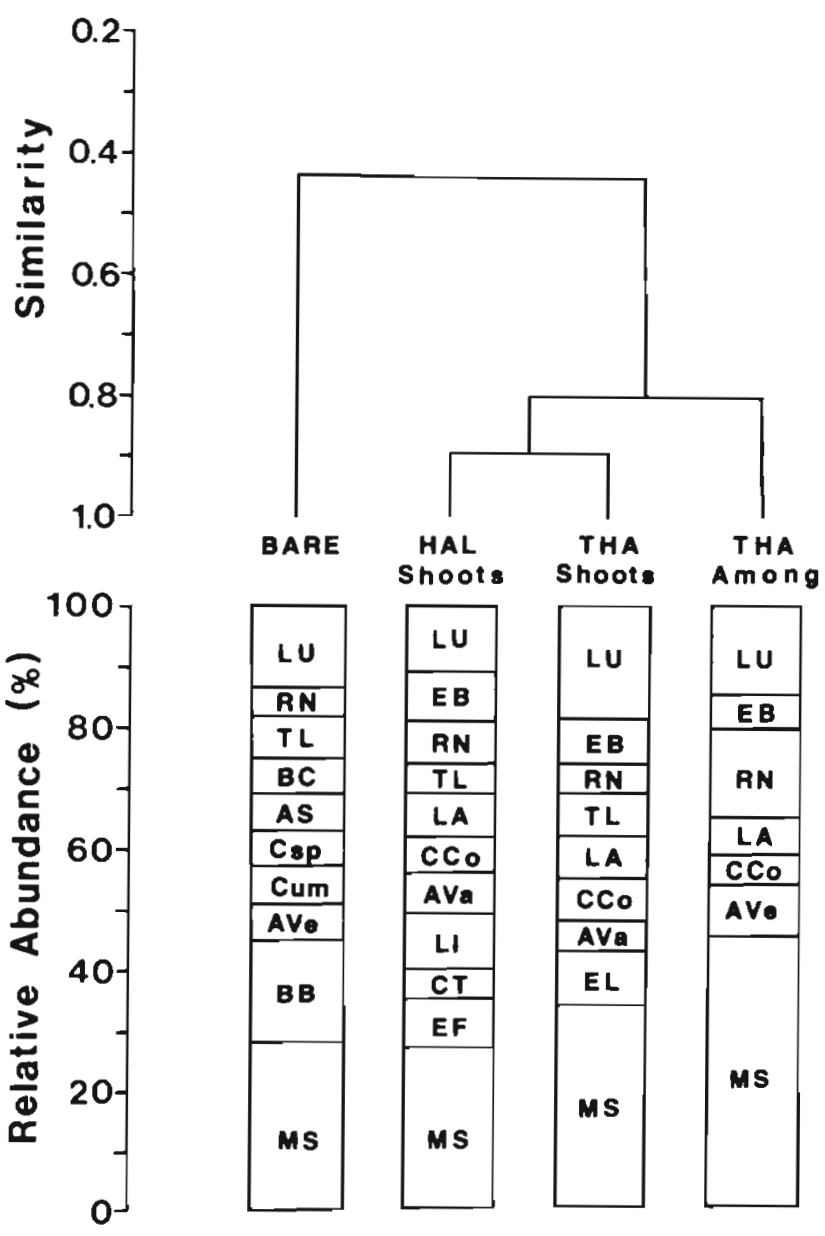

Fig. 2. Comparison of the crustacean fauna associated with 4 grass bed substrata: a large bare patch (BARE), sandy areas among Thalassia testudinum shoots (THA Among), T. testudinum (THA Shoots) and Halodule wrightii (HAL Shoots) shoots. Dendrogram: cluster analysis of crustacean similarity among substrata using index 'rho'. Histograms: relative abundance of crustacean species comprising $4 \%$ or more of the number of individuals per substratum. AS: Ambidexter symmetricus; $\mathrm{AVa}$ : Ampelisca vadorum; $\mathrm{AVe}$ : $\mathrm{A}$. verrilli; $\mathrm{BB}$ : Bowmaniella brasiliensis; BC: Batea catharinensis; CCo: Cymadusa compta; Csp.: Callianassa sp.; CT: Cerapus sp. (cf. tubularis); Cum: Cumacean; EB: Erichthonius brasiliensis; EF: Erichsonella filiformis; EL: Elasmopus levis; LA: Lysianassa alba; LI: Luconacia incerta; LU: Lembos unifasciatus; MS: Iniscellaneous species; RN: Rudilemboides naglei; TL: Tethygeneia Iongleyi

affected by the amount of plant material present than epifaunal species living directly on the seagrass blades. Comparisons of individual species abundances between the vegetated substrata using numbers per plant weight and numbers per surface area were identical, yet, both yielded strikingly different results than those observed with abundance per core (Table 6). Seven of the dominant species had significantly greater abundances per plant weight (or surface area) on Halodule wrightii while only 2 species appeared in greater numbers on Thalassia testudinum (t-tests, 2- tailed; $\mathrm{p}<0.01)$. H. wrightii supported greater abundances per plant weight of the amphipods Batea catharinensis, Cerapus sp., Cymadusa compta, Grandidierella bonnieroides, Luconacia incerta and Rudilemboides naglei and the isopod Erichsonella filiformis. The amphipod Elasmopus levis and the caridean shrimp Hippolyte zostericola were more numerous on $T$. testudinum.

Although one might expect to find a similar number of significant differences for any of the above habitat contrasts out of this set of 24 species strictly on the basis of chance collections from patchy distributions, the pattern of significance for particular species in this study does not appear to be random. For all species examined, a consistency of significance over all sampling dates argues that these abundance differences are real. None of the species occurred in significantly greater abundance on one substratum at one date and the other substratum on another date.

\section{DISCUSSION}

\section{Comparison between vegetated and unvegetated substrata}

Macrophyte biomass was a major factor influencing the spatial distribution of grass bed crustaceans in Apalachee Bay. Vegetated microhabitats consistently supported greater abundance and species richness than unvegetated areas. However, species richness differences appeared directly related to abundance, and thus, indirectly related to the presence of vegetation. Densities (ind $\mathrm{m}^{-2}$ ) in vegetated zones were up to $6 \frac{1 / 2}{2}$ times that in bare areas while total number of species was $40 \%$ greater on seagrass relative to bare substrata (42 species total in unvegetated versus 59 species in grass regions).

High numbers of individuals and species associated with macrophytes have occurred elsewhere in Thalassia testudinum, and Halodule wrightii beds (O'Gower and Wacasey, 1967; Santos and Simon, 1974; Stoner, 1980a, 1983; Virnstein et al., 1983) and in Zostera meadows (Orth, 1973, 1977; Heck and Orth, 1980a) relative to bare areas. Several explanations may account for these observed increased numbers in vegetated compared with unvegetated habitats. The presence of macrophytes can cause increases in the amount of physical structure (usable as living space), numbers of microhabitats, sediment deposition and stabilization, dampening of hydrodynamic effects, food resources and protection from predators (Heck and Wetstone, 1977; Kikuchi and Pérès, 1977). Increasing evidence suggests that seagrasses are quite effective in mediating predation (Nelson, 1979, 1981; Stoner, 1979, 
Table 6. Comparisons of abundances between vegetated and unvegetated substrata, and between Halodule wrightii and Thalassia testudinum substrata for dominant crustaceans (each species constitutes $1 \%$ or more of the total numbers of individuals collected over all substrata) ( $t$-tests with probabilities indicated below table)

\begin{tabular}{|c|c|c|c|}
\hline \multirow[t]{2}{*}{ Dominant species } & \multirow{2}{*}{$\begin{array}{c}\text { Vegetated vs. unvegetated } \\
\text { Abundance } \\
\text { per core }\end{array}$} & \multicolumn{2}{|c|}{ Halodule vs. Thalassia } \\
\hline & & $\begin{array}{l}\text { Abundance } \\
\text { per core }\end{array}$ & $\begin{array}{l}\text { Abundance per } \\
\text { plant weight }\end{array}$ \\
\hline \multicolumn{4}{|l|}{ Amphipoda } \\
\hline Lembos unifasciatus & $V^{\cdots} \cdot$ & $\mathrm{T} \cdots$ & ns \\
\hline Erichthonius brasiliensis & $v^{\cdots}$ & ns & ns \\
\hline Lysianassa alba & $v^{\bullet}$ & ns & - \\
\hline Rudilemboides naglei & $v^{\cdots} \cdots$ & ns & $\mathrm{H}^{\cdots}$ \\
\hline Cymadusa compta & $v^{\prime} \cdot$ & $\mathrm{T}^{\bullet}$ & $\mathrm{H}^{\cdots} \cdot$ \\
\hline Tethygeneia longleyi & $\mathrm{V} \cdots$ & $T^{*}$ & ns \\
\hline Elasmopus levis & $v^{\cdots} \cdots$ & $\mathrm{T} \cdots$ & $T^{\cdots} \cdots$ \\
\hline Ampelisca vadorum & $\mathrm{V} \cdots$ & ns & - \\
\hline Luconacia incerta & $V^{\prime} \cdots$ & $\mathrm{H}^{*}$ & $\mathrm{H}^{\cdots} \cdot$ \\
\hline Cerapus sp. (cf. tubularis) & $V^{\cdots} \cdot$ & ns & $\mathrm{H}^{* *}$ \\
\hline Ampithoe longimana & $V^{\cdots} \cdot$ & $T^{*}$ & ns \\
\hline Lembos rectangulatus & $\mathrm{V}^{*}$ & ns & ns \\
\hline Ampelisca verrilli & $\mathrm{ns}$ & ns & - \\
\hline Batea catharinensis & $\mathrm{V} \cdot \cdots$ & $\mathrm{H}^{*}$ & $\mathrm{H}^{*}$ \\
\hline Carinobatea carinata & $V^{\prime \cdots}$ & $\mathrm{T}^{*}$ & ns \\
\hline Photis macromanus & $V^{\cdots}$ & $T^{\bullet}$ & ns \\
\hline Gitanopsis tortugae & $\mathrm{V}^{\cdots}$ & $\mathrm{T}^{\cdots} \cdot$ & ns \\
\hline Grandidierella bonnieroides & $V^{\cdots}$ & $\mathrm{H}^{*}$ & $\mathrm{H}^{\cdots}$ \\
\hline \multicolumn{4}{|l|}{ Decapoda } \\
\hline Pagurus maclaughlinae & $v^{\cdots} \cdot$ & ns & ns \\
\hline Hippolyte zostericola & ns & $\mathrm{T}^{\bullet}$ & $\mathrm{T}^{*} \cdot$ \\
\hline \multicolumn{4}{|l|}{ Miscellaneous Taxa } \\
\hline Erichsonella filiformis & $v^{\cdots} \cdot$ & $\mathrm{H}^{\cdots} \cdots$ & $\mathrm{H}^{\cdots} \cdot$ \\
\hline Hargeria rapax & $\mathrm{V}^{\cdots} \cdot$ & $T^{*}$ & ns \\
\hline Paracerceis caudata & $V^{*}$ & ns & ns \\
\hline Cumacean spp. & ns & ns & - \\
\hline
\end{tabular}

1982; Heck and Orth, 1980b; Coen et al., 1981; Heck and Thoman, 1981; Peterson, 1982; Leber, 1983).

Both abundance and diversity of crustaceans were strongly correlated with macrophyte biomass over the 4 grass bed habitats. Similarly, high correlations of animal densities with plant weight have been reported between Thalassia testudinum-dominated sites (Heck and Wetstone, 1977; Stoner, 1980a) as well as within sites in T. testudinum, Halodule wrightii and Syringodium filiforme beds (Stoner, 1983). While these correlations may be significant, Stoner (1983) warns that both animal abundance and plant biomass may be functions of yet another variable, water temperature, which affects both faunal reproductive periodicity and seasonal plant growth. In the present study, macrophyte biomass within each substratum varied little over the sampling dates. Relatively high abundances of crustaceans in May appeared correlated with spring reproductive peaks (Lewis, unpubl.) while lower abundances in Sep were coupled to high summer fish predation (Stoner, 1979, 1980b).
The most pronounced differences in species composition and relative abundance in this study appear related to the presence or absence of vegetation. As noted also by Stoner (1980a) for between-site comparisons, densities of epifaunal organisms (especially amphipods) in this study correlated positively with above-ground seagrass biomass. Increased surface area for living space, food resources and predation protection provided by grass blades and epiphytes may account for this observation. However, unlike studies by Orth (1977) and Stoner (1980a), infaunal densities were unrelated to below-ground (rhizome) biomass. Orth (1977), observing a positive relation between infaunal density and below-ground biomass, suggested that a dense rhizome mat offered infaunal organisms a refugium from predators (especially the blue crab Callinectes sapidus). Stoner (1980a), noting an inverse relation between infaunal density and below-ground plant biomass, believed that increased rhizome material inhibited infaunal burrowing and tube building. However, no evidence from the present 
study supported either of these notions. While the dense mat of rhizomes occurring close to the sediment surface in Halodule wrightii stands might be expected to affect activities in this microhabitat, present observations do not confirm this idea. In fact, abundances of infauna, while significantly greater in vegetated relative to unvegetated areas, were similar between the two vegetated zones. Thalassia testudinum rhizomes, although large in size, occur relatively deep and well below the surface sediment layer used by most organisms; interference is probably minimal.

Most species found in this study occurred in more than one microhabitat, yet relative abundances of each species varied markedly over substrata. Excluding species occurring once in a particular habitat, only 5 species (Bowmaniella dissimilis, Callianassa sp., Monoculodes sp., Penaeus duorarum, Processa bermudensis) occurred on a single substratum; 3 of these species were rare with abundances of three individuals or less. Several, more abundant species appeared restricted to either unvegetated (Bowmaniella brasiliensis) or vegetated areas (Alpheus normanni, Cleantis planicauda, Edotea montosa, Epialtus dilatatus, Erichthonius sp., Latreutes fucorum, Lembos smithi, Neopanope texana, Pelia mutica, Thor dobkini).

Most of the dominant species (species constituting $1 \%$ or more of the total individuals collected over all substrata) were significantly more abundant in vegetated microhabitats. While undoubtedly receiving protection from predation in seagrass areas, many of these species also appear intimately linked to their vegetated microhabitats through their feeding strategies. Although few amphipod species actually feed directly on Thalassia testudinum or Halodule wrightii shoots, many graze surface epiphytes, bacteria and trapped detritus from the leaf blades (Zimmerman et al., 1979; Howard, 1982). Likewise, the caridean shrimp Alpheus normanni and the xanthid crab Neopanope texana are known herbivores, feeding heavily on $T$. testudinum and seagrass detritus (Leber, 1983). The majid crab Epialtus dilatatus consumes large quantities of calcareous algae encrusting the surface of T. testudinum blades (Leber, 1983). Presumably, these species could not survive well in unvegetated areas where their preferred food is less abundant; distribution patterns should reflect this survivorship.

\section{Comparison between vegetated substrata}

Surprisingly, no significant differences appeared in crustacean densities or species richness between the 2 vegetation types. Although Thalassia testudinum consistently supported higher abundance and diversity values than Halodule wrightii, variability was high resulting in lack of significance. Kikuchi and Pérès (1977) hypothesized that thin-bladed parvozosterids (e.g. H. wrightii) should support a different fauna than wide-bladed magnozosteroids (e.g. $T$. testudinum) because of their different morphologies. Specifically, magnozosterids should harbor greater numbers and species of animals than parvozosterids because of their relatively greater surface areas, increased shading effects and greater numbers of microhabitats created by the wide blades. Stoner (1982) demonstrated that predation efficiency within a grass bed may also be a function of seagrass growth form. He observed predation efficiency for pinfish (Lagodon rhomboides) capturing amphipod prey to be highest in $H$. wrightii relative to $T$. testudinum and Syringodium filiforme. While the Kikuchi-Pérès hypothesis was partially confirmed by field studies in the Indian River lagoon, Florida (Stoner, 1983), densities of macrofauna in Apalachee Bay (present study) were similar between vegetation types and did not display the predicted pattern. In fact, numbers of individuals per gram dry plant weight or per unit plant surface area were higher in $H$. wrightii than in $T$. testudinum. This difference was magnified in May during a period of maximum animal abundance (Fig. 1).

Stoner (1982) suggested that distribution patterns in grass beds may result from at least 2 factors: faunal habitat preferences and predation effects. Amphipods, when experimentally tested with combinations of 3 seagrasses in equal biomass, preferred Halodule wrightii, with its high surface area to biomass ratio, over either Thalassia testudinum or Syringodium filiforme (Stoner, 1980c). When equal surface areas were presented, no preference was observed. Stoner concluded that surface area was the major factor influencing amphipod substratum choice. Responses were not made to specific seagrass species, only to a particular morphological characteristic of the vegetation. Confounding predictions based on this work is the observation that foraging efficiency by pinfish on amphipods was greatest in $H$. wrightii (Stoner, 1982). Clearly, the choice of habitat with highest predation risk seems nonadaptive, if all other factors related to the habitats are equal; no doubt, other factors are not equal.

While Stoner (1983) has invoked high predation pressure to explain low peracarid abundance in Indian River Halodule wrightii beds, results of the present study suggest that habitat preference may have more marked effects on faunal organization in Apalachee Bay than in the Indian River system. Fewer than $25 \%$ of the 24 dominant crustaceans associated with vegetated substrata in Apalachee Bay occurred in significantly greater abundance per core on one seagrass relative to the other (Table 6). Three species occurred 
in greater abundance on Thalassia testudinum; only 1 species was more numerous on $H$. wrightii. However, when abundances were compared per plant weight (or per plant surface area), 7 species had significantly greater abundance on $H$. wrightii, while 2 species were more numerous on $T$. testudinum. These abundance differences between seagrass species were unpredicted in light of previously described studies (Stoner, 1980c, 1982). Although little direct evidence explaining these species patterns exists, several mechanisms are suggested. In some cases body morphology may place constraints on the choice of microhabitat. The caprellid amphipod Luconacia incerta uses modified walking limbs to cling to the tips of grass blades while foraging in the water column for food with its gnathopods. The thin blades of $H$. wrightii may offer a surface more easily gripped than the wide $T$. testudinum blades. Similarly, the isopod Erichsonella filiformis, with its elongated body, may cling to and move about on slender blades more easily than wide ones. Abundances of both of these species were significantly greater on $H$. wrightii than on $T$. testudinum. Alternatively, these elongated body forms may be less conspicuous to predators on thin $H$. wrightii relative to wide $T$. testudinum blades. Stout-bodied species (e.g. Elasmopus levis. Hippolyte zostericola) may be more visible to predators on a slender substratum; these species may obtain greater protection from wide relative to narrow blades. Predation rates may be influenced by size, shape, color and behavior of prey relative to the background microhabitat (Zaret and Kerfoot, 1975; Stein, 1977; Nelson, 1979; Vinyard, 1980; Main, 1983).

Epiphyte biomass and species composition may also influence crustacean distribution patterns by affecting food availability and grazing strategies. While Humm (1964) characterized the epiphytes of Thalassia testudinum, little is known concerning those species associated with Halodule wrightii. Observations from Apalachee Bay sites suggest that at least qualitative differences in epiphyte composition occur between the 2 seagrasses. Encrusting coralline algae (e.g. Melobesia sp. and Fosliella sp.) were common on wide $T$. testudinum blades, yet seldom occurred on $H$. wrightii. Diatoms and filamentous green and red algae predominated on the $H$. wrightii blades. Zimmerman et al. (1979) reported that the amphipod Cymadusa compta preferred grazing the epiphytes of $H$. wrightii over those found on other macrophytes. In the present study, $H$. wrightii supported greater $C$. compta abundance per plant weight (or surface area) than $T$. testudinum.

Lack of discrete faunal assemblages associated with specific vegetation types has been reported for polychaetes (Santos and Simon, 1974) and peracarids (Stoner, 1983) on seagrasses, and for crustaceans on macroalgae (Lewis, 1982). In all cases, however, differences in relative abundances of individual species within the faunal assemblage present occurred over seasons and by habitats. In studies where distinct macrofaunal assemblages were present in particular microhabitats (Ledoyer, 1962; O'Gower and Wacasey, 1967), various sediment and hydrographic differences among sites precluded conclusions concerning plantanimal interactions. Since all other examined factors were identical for the microhabitats in this study, faunal differences appear directly related to differences in the macrophyte species present.

Thus, while initial observations suggested that faunal organization in seagrass meadows is simply a function of plant biomass, closer examination revealed the influence of macrophyte species composition. Despite significant correlations between plant biomass and both crustacean abundance and species number, the 2 vegetation types affected their associated faunas quite differently. Undoubtedly, these patterns of crustacean distribution within grass beds resulted from the combined effects of microhabitat preference and predation pressure, both of which are strongly influenced by the amount and kind of vegetation present.

Acknowledgements. I thank K. Brady, H. Greening, L. Goodman, K. M. Leber, K. Main and S. Roberts for invaluable field assistance. R. K. Howard, K. M. Leber, K. Main, A. W. Stoner and R. W. Virnstein provided thoughtful reviews of the manuscript in various stages of completion. Financial aid for field work came in part from R. J. Livingston, Florida State University. I gratefully acknowledge Harbor Branch Institution, Inc., for supporting the author with a postdoctoral fellowship during preparation of this manuscript.

\section{LITERATURE CITED}

Abele, L. G. (1970). The marine decapod Crustacea of the northeastern Gulf of Mexico. M. S. thesis, Florida State University, Tallahassee

Bittaker, H. F., Iverson, R. L. (in press). Seagrass distribution in the eastern Gulf of Mexico. Estuar. coast. Shelf Sci.

Bousfield, E. L. (1973). Shallow-water gammaridean Amphipoda of New England. Cornell University Press, Ithaca, N.Y.

Brook, I. M. (1978). Comparative macrofaunal abundance in turtlegrass (Thalassia testudinum) communities in south Florida characterized by high blade density. Bull. mar. Sci. 28: 212-217

Clements, W. H., Livingston, R. J. (1983). Overlap and pollution-induced variability in the feeding habits of filefish (Pisces: Monacanthidae) in Apalachee Bay, Florida. Copeia 1983: 331-338

Coen, L. D., Heck, K. L., Jr., Abele, L. G. (1981). Experiments on competition and predation among shrimps of seagrass meadows. Ecology 62: 1484-1493

den Hartog, C. (1967). The structural aspect in the ecology of seagrass communities. Helgoländer wiss. Meeresunters. 15: $648-659$

Dugan, P. J., Livingston, R. J. (1982). Long-term variation of 
macroinvertebrate assemblages in Apalachee Bay, Florida. Estuar. coast. Shelf Sci. 14: 391-403

Greening, H. S., Livingston, R. J. (1982). Diel variation in the structure of seagrass-associated epibenthic macroinvertebrate communities. Mar. Ecol. Prog. Ser. 7: 147-156

Heck, K. L., Jr. (1976). Community structure and the effects of pollution in seagrass meadows and adjacent habitats. Mar. Biol. 35: 345-357

Heck, K. L., Jr., Orth, R. J. (1980a). Structural components of eelgrass (Zostera marina) meadows in the lower Chesapeake Bay - decapod Crustacea. Estuaries 3: 289-295

Heck, K. L., Jr., Orth, R. J. (1980b). Seagrass habitats: the role of habitat complexity, competition and predation in structuring associated fish and motile macroinvertebrate assemblages. In: Kennedy, V. S. (ed.) Estuarine perspectives. Academic Press, New York, p. 449-464

Heck, K. L., Jr., Thoman, T. A. (1981). Experiments on predator-prey interactions in vegetated aquatic habitats. $\mathrm{J}$ exp. mar. Biol. Ecol. 53: 125-134

Heck, K. L., Jr., van Belle, G., Simberloff, D. S. (1975). Explicit calculation of the rarefaction diversity measurement and the determination of sufficient sample size. Ecology 56 : 1159-1161

Heck, K. L., Jr., Wetstone, G. S. (1977). Habitat complexity and invertebrate species richness and abundance in tropical seagrass meadows. J. Biogeogr. 4: 135-142

Hooks, T. A., Heck, K. L., Jr., Livingston, R. J. (1976). An inshore marine invertebrate community: structure and habitat associations in the northeastern Gulf of Mexico. Bull. mar. Sci. 26: 99-109

Howard, R. K. (1982). Impact of feeding activities of epibenthic amphipods on surface-fouling of eelgrass leaves, Aquat. Bot. 14: 91-97

Humm, H. J. (1964). Epiphytes of the seagrass Thalassia testudinum in Florida. Bull. mar. Sci. 14: 306-341

Kikuchi, T., Pérès, J, M. (1977). Animal communities in seagrass beds: a review. In: McRoy, C. P., Helfferich, C. (ed.) Seagrass ecosystems: a scientific perspective. Marcel Dekker, New York, p. 147-193

Lance, G. N., Williams, W. T. (1967). A general theory of classificatory sorting strategies. I. Hierarchical systems. Comp. J. 9: 373-380

Leber, K. M., III. (1983). Feeding ecology of decapod crustaceans and the influence of vegetation on foraging success in a subtropical seagrass meadow. $\mathrm{Ph}$. D. dissertation, Florida State University, Tallahassee

Ledoyer, $M$. (1962). Etude de la faune vagile des herbiers superficiels des Zostéracées et de quelques biotopes d'algues littorales. Recl Trav. Stn mar. Endoume 25: 117-235

Lewis, F. G., III. (1982). Habitat complexity in a subtropical seagrass meadow: the effects of macrophytes on species composition and abundance in benthic crustacean assemblages. Ph. D. dissertation, Florida State University, Tallahassee

Lewis, F. G., III, Stoner, A. W. (1981). An examination of methods for sampling macrobenthos in seagrass meadows. Bull. mar. Sci. 31: 116-124

Lewis, F. G., III, Stoner, A. W. (1983). Distribution of macrofauna within seagrass beds: an explanation for patterns of abundance. Bull. mar. Sci. 33: 296-304

Livingston, R. J. (1975). Impact of kraft pulp mill effluents on estuarine and coastal fishes in Apalachee Bay, Florida. Mar. Biol. 32: 19-48

Livingston, R. J. (1982). Trophic organization of fishes in a coastal seagrass system. Mar. Ecol. Prog. Ser. 7: 1-12

Livingston, R. J., Lloyd, R. S., Zimmerman, M. S. (1976).
Determination of sampling strategy for benthic macrophytes in polluted and unpolluted coastal areas. Bull. mar. Sci. 26: $569-575$

Main, K. L. (1983). Behavioral response of a caridean shrimp to a predatory fish. Ph. D. dissertation, Florida State University, Tallahassee

Martin, F. D., Cooper, M. (1981). A comparison of fish faunas found in pure stands of two tropical Atlantic seagrasses, Thalassia testudinum and Syringodium filiforme. Northeast Gulf Sci. 5: 31-37

Matusita, K. (1955). Decision rules based on the distance for problems of fit, two samples and estimation. Ann. math. Statist. 26: 631-640

Meeter, D. A., Livingston, R. J. (1978). Statistical methods applied to a four-year multivariate study of a Florida estuarine system. In: Dickson, K. L., Cairns, J., Jr., Livingston, R. J. (ed.) Biological data in water pollution assessment: quantitative and statistical analyses. American Society for Testing and Materials, Spec. Tech. Publ. 652: 53-67

Myers, J. L. (1979). Fundamentals of experimental design. Allyn and Bacon, Inc., Boston

Nelson, W. G. (1979). Experimental studies of selective predation on amphipods: consequences for amphipod distribution and abundance. J. exp. mar. Biol. Ecol. 38: 225-245

Nelson, W. G. (1981). Experimental studies of decapod and fish predation on seagrass macrobenthos. Mar. Ecol. Prog. Ser. 5: 141-149

O'Gower, A. K., Wacasey, J. W. (1967). Animal communities associated with Thalassia, Diplanthera, and sand beds in Biscayne Bay. I. Analysis of communities in relation to water movements. Bull. mar. Sci. 17: 175-210

Orth, R. J. (1973). Benthic infauna of eelgrass, Zostera marina, beds. Chesapeake Sci. 14: 258-269

Orth, R. J. (1977). The importance of sediment stability in seagrass communities. In: Coull, B. C. (ed.) Ecology of marine benthos. University of South Carolina Press, Columbia, p. 281-300

Peterson, C. H. (1982). Clam predation by whelks (Busycon spp.): experimental tests of the importance of prey size, prey density and seagrass cover. Mar. Biol. 66: 159-170

Ryan, J. D. (1981). Diel predator-prey relationships in a subtropical seagrass meadow: Apalachee Bay, Florida. M. S. thesis, Florida State University, Tallahassee

Santos, S. L., Simon, J. L. (1974). Distribution and abundance of the polychaetous annelids in a south Florida estuary. Bull. mar. Sci. 24: 669-689

Simberloff, D. S. (1978). Use of rarefaction and related methods in ecology. In: Dickson, K. L., Cairns, J., Jr., Livingston, R. J. (ed.) Biological data in water pollution assessment: quantitative and statistical analyses. American Society for Testing and Materials, Spec. Tech. Publ. 652: $150-165$

Stein, R. A. (1977). Selective predation, optimal foraging and the predator-prey interaction between fish and crayfish. Ecology 58: 1237-1253

Stoner, A. W. (1979). Species-specific predation on amphipod Crustacea by the pinfish Lagodon rhomboides: mediation by macrophyte standing crop. Mar. Biol. 55: 201-207

Stoner, A. W. (1980a). The role of seagrass biomass in the organization of benthic macrofaunal assemblages. Bull. mar. Sci. 30: 537-551

Stoner, A. W. (1980b). Abundance, reproductive seasonality and habitat preferences of amphipod crustaceans in seagrass meadows of Apalachee Bay, Florida. Contrib. mar Sci., Univ. Texas 23: 63-77

Stoner, A. W. (1980c). Perception and choice of substratum by 
epifaunal amphipods associated with seagrasses. Mar. Ecol. Prog. Ser. 3: 105-111

Stoner, A. W. (1980d). Feeding ecology of Lagodon rhomboides (Pisces: Sparidae): variation and functional responses. Fish. Bull. U.S. 78: 337-352

Stoner, A. W. (1982). The influence of benthic macrophytes on the foraging behavior of pinfish, Lagodon rhomboides (Linnaeus). J. exp. mar. Biol. Ecol. 58: 271-284

Stoner, A. W. (1983). Distributional ecology of amphipods and tanaidaceans associated with three sea grass species. J. Crust. Biol. 3: 505-518

Stoner, A. W., Livingston, R. J. (1981). Distributional ecology and food habits of the banded blenny Paraclinus fasciatus (Clinidae): a resident in a mobile habitat. Mar. Biol. 56: 239-246

van Belle, G., Ahmad, I. (1974). Measuring affinity of distribution. In: Proschan, F., Serfling, R. J. (ed.) Reliability and biometry: statistical analysis of lifelength. S.I.A.M., Philadelphia, p. 651-668

Vinyard, G. L. (1980). Differential prey vulnerability and predator selectivity: effects of evasive prey on bluegill
(Lepomis macrochirus) and pumkin seed (L. gibbosus) predation. Can. J. Fish. aquat. Sci. 37: 2294-2299

Virnstein, R. W., Mikkelsen, P. S., Cairns, K. D., Capone, M. A. (1983). Seagrass beds versus sand bottoms: the trophic importance of their associated benthic invertebrates. Florida Sci. 46: 363-381

Williams, A. B. (1965). Marine decapod crustaceans of the Carolinas. Fish. Bull. U.S. 65: 1-298

Young, P. C. (1981). Temporal changes in the vagile epibenthic fauna of two seagrass meadows (Zostera capricornis and Posidonia australis). Mar. Ecol. Prog. Ser. 5: 91-102

Zaret, T. M., Kerfoot, W. C. (1975). Fish predation on Bosmina longirostris: body-size selection versus visibility selection. Ecology 56: 232-237

Zimmerman, M. S., Livingston, R. J. (1976). The effects of kraft mill effluents on benthic macrophyte assemblages in a shallow bay system (Apalachee Bay, North Florida, USA). Mar. Biol. 34 : 297-312

Zimmerman, M. S., Livingston, R. J. (1979). Dominance and distribution of benthic macrophyte assemblages in a north Florida estuary (Apalachee Bay, Florida). Bull. mar. Sci. 29: $27-40$

This paper was submitted to the editor; it was accepted for printing on April 28, 1984 